\title{
Dimethylation of Adenine and the Resistance of Streptomyces erythraeus to Erythromycin
}

\author{
By RICHARD H. SKINNER AND ERIC CUNDLIFFE* \\ Department of Biochemistry, University of Leicester, Adrian Building, University Rd, \\ Leicester LEI 7RH, U.K.
}

(Received 22 February 1982)

The erythromycin-producing organism, Streptomyces erythraeus, is highly resistant to erythromycin and also to other members of the macrolide, lincosamide and streptogramin type B (MLS) group of antibiotics. Resistance results from the presence of a single residue of $N^{6}, N^{6}$-dimethyladenine in $S$. erythraeus $23 \mathrm{~S}$ rRNA. The enzyme which produces this residue ('the erythromycin-resistance methylase') has been isolated and characterized in vitro.

\section{INTRODUCTION}

The macrolide antibiotic, erythromycin, is produced by Streptomyces erythraeus (McGuire et al., 1952), an organism which is resistant to erythromycin and also to other members of the 'MLS' (macrolide, lincosamide and streptogramin B) group of antibiotics (Graham \& Weisblum, 1979). The MLS-resistance phenotype was first observed in certain clinical strains of Staphylococcus and Streptococcus in which inducible resistance to these drugs was associated with the appearance of $N^{6}, N^{6}$-dimethyladenine in 23S rRNA (Lai \& Weisblum, 1971). Subsequently, it was shown that the ribosomes of such strains of Staphylococcus aureus were resistant to MLS antibiotics as a direct consequence of the presence of dimethyladenine in their 23S RNA (Lai et al., 1973). More recently, the methylase responsible for this modification has been purified from Bacillus subtilis carrying the staphylococcal plasmid pE194 (Shivakumar \& Dubnau, 1981).

Evidence that the MLS-resistance phenotype of $S$. erythraeus was a property of its ribosomes was presented by Teraoka and Tanaka (1974), who showed that they were resistant to various macrolides and also to lincomycin. This, together with the observation that the 23S RNA of $S$. erythraeus contained $N^{6}, N^{6}$-dimethyladenine, led to the suggestion that the mechanism of MLSresistance in $S$. erythraeus might be similar to that in Staphylococcus (Graham \& Weisblum, 1979). Our interest in the strategies by which antibiotic producing organisms avoid the problem of auto-toxicity encouraged us to test this hypothesis experimentally.

In order to do this, it was first necessary to isolate the methylase responsible for the presence of dimethyladenine in $S$, erythraeus $23 \mathrm{~S}$ rRNA. Then, the enzyme was used to modify heterologous rRNA in vitro so that the properties of reconstituted ribosomal particles containing specifically methylated RNA could be examined. Given the relative ease with which 50 S ribosomal subunits of Bacillus stearothermophilus can be assembled in vitro (Fahnestock et al., 1974), we decided to examine the effects of RNA methylation in this system.

\section{METHODS}

Growth of cells and preparation of extracts. Spores of S. erythreus (NRRL 2338) were used to inoculate fiasks of tryptic soy broth (Difco) and cultures were grown with shaking at $37^{\circ} \mathrm{C}$ for $36 \mathrm{~h}$. Cells were harvested by centrifugation at $15000 \mathrm{~g}$ for $5 \mathrm{~min}$, followed by two cycles of resuspension in buffer containing $10 \mathrm{mM}-\mathrm{Tris} / \mathrm{HCl}$ (pH 7.6 at $20^{\circ} \mathrm{C}$ ), $10 \mathrm{mM}-\mathrm{MgCl}_{2}, 50 \mathrm{mM}-\mathrm{NH}_{4} \mathrm{Cl}$ and $3 \mathrm{~mm}-2$-mercaptoethanol. Cell breakage was achieved by two

Abbreviations: HVPE, high-voltage paper electrophoresis: MLS, macrolide, lincosamide, streptogramin B group of antibiotics; SAH, $S$-adenosylhomocysteine; SAM, $S$-adenosyl-L-methionine. 
passes through a French pressure cell (precooled to $0^{\circ} \mathrm{C}$ ) at 70 to $80 \mathrm{MPa}$. Deoxyribonuclease $\left(5 \mu \mathrm{g} \mathrm{ml} \mathrm{m}^{-1} \mathrm{final}\right.$ concentration) was added between pressings. The extract was then centrifuged at $30000 \mathrm{~g}$ for $20 \mathrm{~min}$ to obtain the 'S30' fraction.

Chemostat-grown cells of $B$. stearothermophilus (NCIB 8924) were obtained from the Microbiological Research Establishment, Porton Down, Wilts, U.K. S30 extracts were prepared as described above, except that cells were broken by grinding with alumina.

Preparation of ribosomes and ribosomal subunits. Ribosomal subunits of $B$. stearothermophilus were prepared using the Til 5 zonal rotor as described by Fahnestock et al. (1974). Ribosomal subunits and postribosomal supernatant (SI00) from Escherichia coli MRE 600 were prepared by procedures described previously for Bacillus megaterium (Stark \& Cundliffe, 1979).

Preparation of ribosomal RNA. RNA from 70S ribosomes (RNA70) or 50S subunits (RNA50) was prepared by extraction with urea plus $\mathrm{LiCl}$ and the RNA50 was freed of 5S rRNA and deproteinized to yield 23S rRNA as described by Fahnestock et al. (1974).

Assays of cell-free protein synthesis. The poly(U)-directed synthesis of polyphenylalanine was assayed as described previously (Cundliffe et al., 1979). Here, 50S ribosomal subunits (native or reconstituted) were supplemented with $E$. coli $30 \mathrm{~S}$ subunits, antibiotics (if any) and $E$. coli $\mathrm{S} 100$ prior to assay at $37^{\circ} \mathrm{C}$.

Preparation of 'erythromycin-resistance methylase'. All steps in this procedure were performed at $0-4{ }^{\circ} \mathrm{C}$ unless otherwise stated. Extracts of $S$. erythraeus were prepared as described above and were then centrifuged at $36000 \mathrm{rev} . \mathrm{min}^{-1}$ for $16 \mathrm{~h}$ in the Beckman Ti70 rotor. The pellet of ribosomes and membranes was resuspended in buffer containing $10 \mathrm{~mm}$-Tris/ $\mathrm{HCl}\left(\mathrm{pH} 7.6\right.$ at $20^{\circ} \mathrm{C}$ ), $30 \mathrm{~mm}-\mathrm{MgCl}_{2}, 1 \mathrm{M}-\mathrm{NH}_{4} \mathrm{Cl}$ and $3 \mathrm{mM}-2$-mercaptoethanol. After standing on ice for $5 \mathrm{~h}$, the suspension was layered over an equal volume of the same buffer containing $20 \%$ $(\mathrm{w} / \mathrm{v})$ sucrose and centrifuged at $40000 \mathrm{rev} . \mathrm{min}^{-1}$ for $16 \mathrm{~h}$ in the Ti70 rotor. Ammonium sulphate (23.7 g per 100 $\mathrm{ml}$ ) was added to the resultant supernatant. The precipitate was removed by centrifugation at $30000 \mathrm{~g}$ for $15 \mathrm{~min}$ and discarded. Further ammonium sulphate $(9 \cdot 3 \mathrm{~g}$ per $100 \mathrm{ml})$ was added to the supernatant, which was then recentrifuged as above. The pellet was dissolved in TM buffer $\left(20 \mathrm{mM}-\mathrm{Tris} / \mathrm{HCl} \mathrm{pH} 7.6\right.$ at $20^{\circ} \mathrm{C}, 10 \mathrm{mM}^{-} \mathrm{MgCl}_{2}$, $3 \mathrm{~mm}-2$-mercaptoethanol and $10 \%$ glycerol) and dialysed overnight against TM buffer containing $1 \mathrm{M}-\mathrm{NH}_{4} \mathrm{Cl}$. The enzyme preparation was then diluted tenfold with TM buffer and $0 \cdot 3 \mathrm{~g} \mathrm{SAH-Sepharose} \mathrm{was} \mathrm{added.} \mathrm{This} \mathrm{resin} \mathrm{was}$ prepared by covalent linking of $S$-adenosylhomocysteine (SAH) to Sepharose (Pharmacia) via a six-carbon spacer arm, as described by Izzo \& Gantt (1977). After $10 \mathrm{~min}$ at $20^{\circ} \mathrm{C}$, the suspension was poured into a column $(0.7 \times 4$ $\mathrm{cm}$ ) and washed with $4 \mathrm{vol}$. TM buffer containing $100 \mathrm{mM}-\mathrm{NH}_{4} \mathrm{Cl}$. Methylase activity was eluted with TM buffer containing $1 \mathrm{M}-\mathrm{NH}_{4} \mathrm{Cl}$ and stored at $-70{ }^{\circ} \mathrm{C}$.

Assay of $r$ RNA methylase activity. RNA methylase assays were performed at $37^{\circ} \mathrm{C}$ and contained $50 \mathrm{~mm}$ HEPES/KOH, pH 7.5, $15 \mathrm{mM}$-Tris/ $\mathrm{HCl}$ (pH 7.6 at $20^{\circ} \mathrm{C}$ ), 7.5 mM- $\mathrm{MgCl}_{2}, 200 \mathrm{mM}-\mathrm{NH}_{4} \mathrm{Cl}, 4 \%$ glycerol, 2 mM-2mercaptoethanol, methylase (10-100 units $\mathrm{ml}^{-1}$ ), $0 \cdot 4 \mu \mathrm{M}-\mathrm{RNA} 70$ from $B$. stearothermophilus and $S$-adenosyl-L$\left[\right.$ methyl $\left.{ }^{3} \mathrm{H}\right]$ methionine $\left(\left[{ }^{3} \mathrm{H}\right] \mathrm{SAM}\right)\left[25 \mu \mathrm{Ci} \mathrm{ml}^{-1} ; \mathrm{sp}\right.$. act. $\left.500 \mathrm{mCi} \mathrm{mmol}^{-1}\left(18.5 \mathrm{GBq} \mathrm{mmol}^{-1}\right)\right]$. The incorporation of $\left[{ }^{3} \mathrm{H}\right]$ methyl groups into RNA was measured as previously described (Thompson \& Cundliffe, 1981). One unit of enzyme was defined as the amount that catalysed the incorporation into RNA of 1 pmol methyl groups min $^{-1}$.

Bulk methylation and hydrolysis of RNA. Purified B. stearothermophilus $23 \mathrm{~S}$ rRNA was radioactively methylated as described above. The reaction mixture was desalted on Sephadex G-25 and the RNA was deproteinized with phenol, precipitated with ethanol, and a portion hydrolysed with $1 \mathrm{M}-\mathrm{HCl}$ as described elsewhere (Cundliffe \& Thompson, 1979). Alternatively, methylated RNA was hydrolysed in $1 \mathrm{M}-\mathrm{KOH}$ at $37^{\circ} \mathrm{C}$ for $16 \mathrm{~h}$.

\section{RESULTS}

\section{Purification of a methylase from S. erythraeus}

Extracts of $S$. erythraeus catalysed the methylation of rRNA from $B$. stearothermophilus using $\left[{ }^{3} \mathrm{H}\right] \mathrm{SAM}$ as cofactor (Table 1 ). The methylase activity sedimented with the ribosomes on ultracentrifugation, but was released by the salt-washing procedure. Ammonium sulphate precipitation was then used to concentrate and further purify the enzyme. A significant increase in activity was reproducibly observed at this stage. Finally, the enzyme was bound to an affinity resin (consisting of SAH covalently linked to Sepharose), from which it was eluted by raising the salt concentration.

\section{Identification of the methylated residue}

The identity of the methylated residue(s) produced within rRNA by the partially purified enzyme was established by a combination of high-voltage paper electrophoresis (HVPE) and paper chromatography. Bacillus stearothermophilus $23 \mathrm{~S}$ rRNA was radioactively methylated and hydrolysed with either alkali or acid. Alkaline hydrolysis of RNA degrades it to nucleoside 3'- 


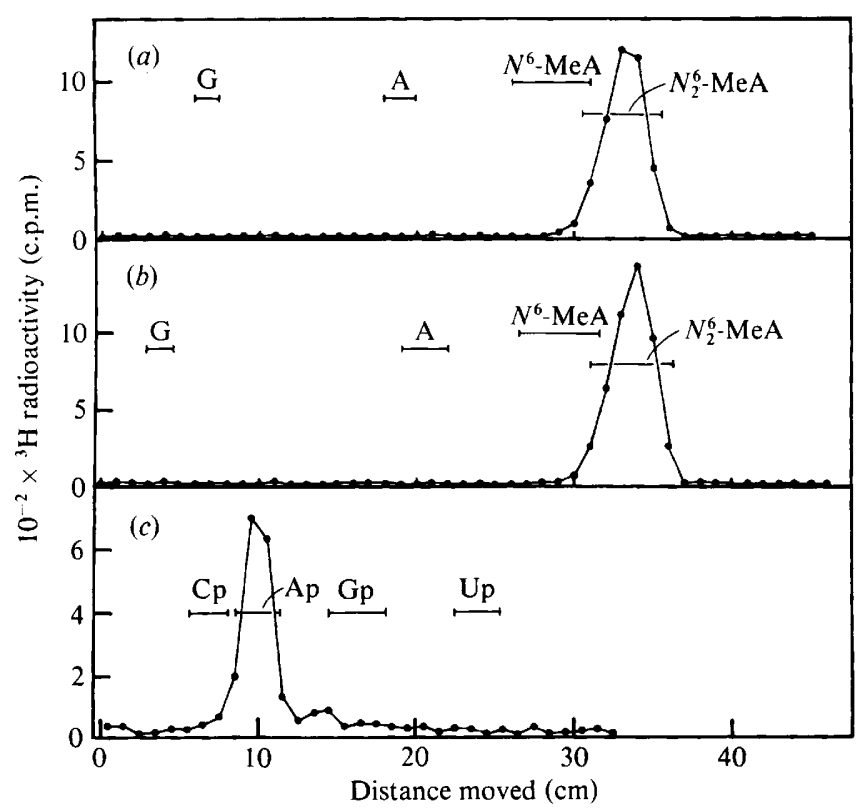

Fig. 1. Identification of methylated residue. Bacillus stearothermophilus 23S RNA was radioactively methylated and hydrolysed as described in Methods. An acid hydrolysate was subjected to descending paper chromatography on Whatman $3 \mathrm{MM}$ paper in solvent containing $(a)$ butan-1-ol/water $(86: 14$, $\mathrm{v} / \mathrm{v}$ ) or (b) propan-2-ol/water/ $\mathrm{NH}_{3}(85: 15: 1 \cdot 3$, by vol.). Alternatively $(c)$, alkali-hydrolysed methylated RNA was subjected to HVPE on Whatman 52 paper at $\mathrm{pH} 3.5$ as described elsewhere (Sanger \& Brownlee, 1967). Markers were detected by UV absorption: $N^{6}$-MeA, $N^{6}$-methyladenine; $N_{2}^{6}$-MeA, $N^{6}, N^{6}$-dimethyladenine; Up, Ap, Gp, Cp, nucleoside 3'-monophosphates.

Table 1. Purification of S. erythraeus rRNA methylase

\begin{tabular}{lcccrr}
\multicolumn{1}{c}{ Stage of purification } & $\begin{array}{c}\text { Protein } \\
(\mathrm{mg})\end{array}$ & $\begin{array}{c}\text { Enzyme } \\
\text { activity } \\
\text { (units) }\end{array}$ & $\begin{array}{c}\text { Specific } \\
\text { activity } \\
\left.\text { (units } \mathrm{mg}^{-1}\right)\end{array}$ & $\begin{array}{c}\text { Purification } \\
\text { factor }\end{array}$ & $\begin{array}{c}\text { Yield } \\
(\%)\end{array}$ \\
S30 & 1031 & 8450 & $8 \cdot 2$ & $1 \cdot 0$ & 100 \\
Ribosomal salt-wash $_{\left(\mathrm{NH}_{4}\right)_{2} \mathrm{SO}_{4}(40-55 \% \text { saturation) }}$ & 333 & 6450 & $19 \cdot 4$ & $2 \cdot 4$ & 76 \\
SAH-Sepharose $^{2}$ & 89 & 9950 & 112 & 14.0 & 118 \\
& $5 \cdot 2$ & 7700 & 1480 & 180 & 91
\end{tabular}

monophosphates, except at residues of $2^{\prime}-O$-methylribose, where dinucleotides are generated (Bock, 1967). Following alkaline hydrolysis and HVPE at pH $3 \cdot 5,\left[{ }^{3} \mathrm{H}\right]$ methyl radioactivity comigrated exclusively with adenosine $3^{\prime}$-monophosphate (Fig. 1). This implied methylation of either the base or the sugar moiety of an adenosine residue; neither methylation affects the charge on the molecule. The identity of the methylated adenosine was established by paper chromatography of acid hydrolysates of methylated RNA. Acid hydrolysis generates pyrimidine nucleoside monophosphates and free purines, together with ribose and inorganic phosphate (Schmidt, 1957), and, of these, only the purine bases migrate from the origin in the chromatographic systems employed here. In both solvent systems used, radioactivity co-migrated with $N^{6}, N^{6}$-dimethyladenine and this was the sole methylated residue (Fig. 1).

\section{Effect of RNA methylation on ribosomes}

The stoichiometry of methylation both of total rRNA (Fig. 2) and of purified 23S rRNA from B. stearothermophilus (results not shown) was about 1.5 methyl groups per (23S) RNA molecule, and all these methyl groups were recovered as dimethyladenine (Fig. 1). Given the previous report that $N^{6}$-monomethyladenine does not occur in the 23S rRNA of B. stearothermophilus or other Gram-positive organisms (Tanaka \& Weisblum, 1975), adenine residues (rather than 


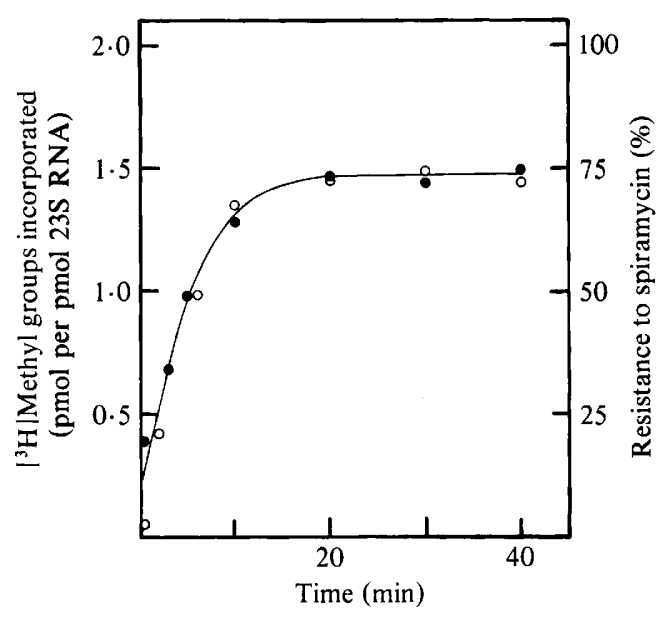

Fig. 2

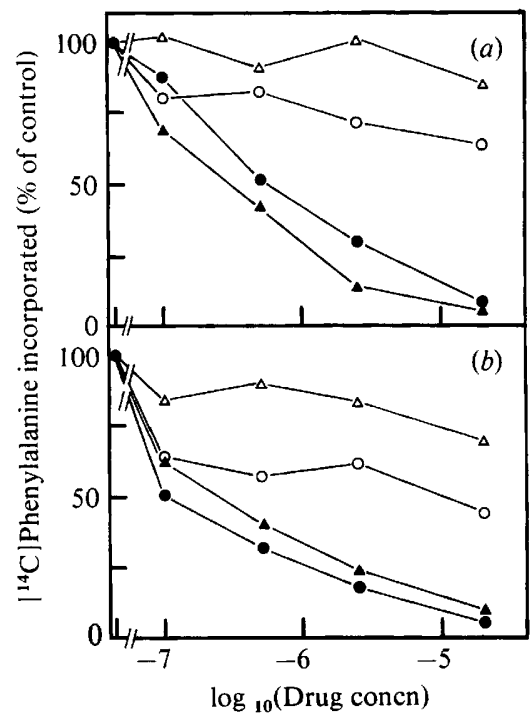

Fig. 3

Fig. 2. Time courses of methylation $(O)$ and acquisition of resistance to spiramycin (O). Methylation reactions contained 100 units methylase $\mathrm{ml}^{-1}$ together with either $\left.{ }^{3} \mathrm{H}\right] \mathrm{SAM}$ or unlabelled SAM $(50 \mu \mathrm{M})$ as cofactor (see Methods). At intervals, samples containing $80 \mathrm{pmol} B$. stearothermophilus RNA70 were removed from the incubation containing unlabelled SAM, rapidly cooled to $0{ }^{\circ} \mathrm{C}$ in the presence of $0.2 \%(\mathrm{w} / \mathrm{v})$ bentonite (Serva) to stop methylation and centrifuged at $12000 \mathrm{~g}$ for $1 \mathrm{~min}$. Ribosomal particles were then reconstituted using RNA in the supernatant together with a 1.5-fold molar excess of B. stearothermophilus 50S subunit proteins as described previously (Fahnestock et al., 1974). Reconstituted particles were precipitated with ethanol $(33 \%, v / v$, final), supplemented with postribosomal supernatant plus $30 \mathrm{~S}$ subunits from $E$. coli and utilized in polyphenylalanine synthesis. In the absence of drug, 4-7 pmol phenylalanine were polymerized per pmol ribosomes in $10 \mathrm{~min}$; otherwise, ribosomes were preincubated with $20 \mu \mathrm{M}$-spiramycin for $10 \mathrm{~min}$ at $37^{\circ} \mathrm{C}$ and their activity over a subsequent 10 min incubation period was expressed as a percentage of the control value. This percentage value was taken as a measure of the resistance of the reconstituted particles to spiramycin. All points represent the means of duplicate determinations.

Fig. 3. Effect of methylation of rRNA on response of reconstituted 50S particles to spiramycin and lincomycin. Reconstituted 50S ribosomal subunits of $B$. stearothermophilus were prepared (as described in the legend to Fig. 2) using RNA70 which had been incubated with methylase (100 units $\mathrm{ml}^{-1}$, for 20 $\mathrm{min}$ ) in the presence $(O)$ or absence $(O)$ of SAM. These were then assayed for activity in polyphenylalanine synthesis in the presence of various concentrations of spiramycin $(a)$ or lincomycin $(b)$ as in the legend to Fig. 2. For comparison, results obtained with native $50 \mathrm{~S}$ subunits of $S$. erythraeus $(\triangle)$ and $B$. stearothermophilus ( $)$ are included. When supplemented with $30 S$ subunits and postribosomal supernatant from $E$. coli these polymerized, respectively, 8 and 15 pmol phenylalanine per pmol ribosomes in $10 \mathrm{~min}$ in the absence of drug. These results are representative of several similar experiments.

monomethyladenine) must be the substrate for the methylase. Accordingly, we conclude that after methylation about $75 \%$ of the $23 \mathrm{~S}$ RNA molecules contained dimethyladenine.

In order to assess the functional significance of such methylation, the properties of reconstituted particles containing methylated 23S RNA were examined. In these experiments, $B$. stearothermophilus RNA was incubated with methylase plus unlabelled SAM as cofactor and was then used in the reconstitution of $50 \mathrm{~S}$ subunits. These were tested, in conjunction with $E$. coli $30 \mathrm{~S}$ subunits, for their response to spiramycin (a macrolide antibiotic which, unlike erythromycin, is an effective inhibitor of cell-free polyphenylalanine synthesis). Reconstituted particles were found to be $75 \%$ resistant to spiramycin when the average stoichiometry of methylation was 1.5 (Fig. 2). Moreover, the time courses of methylation and acquisition of spiramycin resistance were indistinguishable. It is not clear why $25 \%$ of the $B$. stearothermophilus $23 \mathrm{~S}$ RNA molecules were refractory to methylation, since we have obtained stoichiometries of methylation close to 2.0 with rRNA from other sources such as Streptomyces coelicolor and Streptomyces lividans (data 
not shown). Presumably, S. erythraeus rRNA is completely methylated in vivo (i.e. with stoichiometry, in this context, of $2 \cdot 0$ ), thereby accounting for the total insensitivity of its ribosomes to spiramycin (Teraoka \& Tanaka, 1974; see also Fig. 3).

Definitive proof that methylation of rRNA is the cause of MLS resistance is provided in Fig. 3. Reconstituted ribosomes containing methylated RNA were substantially resistant to spiramycin and lincomycin over a wide range of concentrations. In contrast, those containing unmethylated RNA were just as sensitive as control native ribosomes.

\section{DISCUSSION}

A causal connection has been established in this study between the presence of dimethyladenine in S. erythraeus 23S rRNA and the resistance of its ribosomes to MLS antibiotics. As yet, we cannot rigorously exclude the possibility that factors other than RNA methylation might also contribute to the resistance of $S$. erythraeus to these drugs. However, the $S$. erythraeus methylase gene has recently been cloned into $S$. lividans, where it confers the MLS-resistance phenotype (Thompson et al., 1982). Thus, it is now clear that dimethylation of a single adenine residue within 23S rRNA is a necessary and sufficient condition for rendering ribosomes (and organisms) resistant to erythromycin and other MLS antibiotics.

This is the second case in which ribosomal modification has proved to be the mechanism by which an antibiotic-producing organism defends itself against its product. In the first, the thiostrepton-producer, Streptomyces azureus, was found to methylate a specific ribose residue in its 23S rRNA (Cundliffe, 1978; Cundliffe \& Thompson, 1979). It remains to be seen how widespread this type of target-site modification may be among other antibiotic producers; in particular, resistance mechanisms in certain streptomycetes which produce MLS antibiotics other than erythromycin might bear closer scrutiny. In these organisms, induction of resistance to MLS antibiotics has been circumstantially linked with the appearance of either mono- or dimethyladenine, or both, within 23S rRNA (Fujisawa \& Weisblum, 1981). Further biochemical and genetic studies will be necessary to determine whether any causal connection exists between these events.

Clearly, it will be of interest to determine the site of action of the erythromycin-resistance methylase within 23S RNA. Assuming that methylation blocks the binding of MLS antibiotics to the ribosome, such studies should identify the region of 23S RNA present at their binding site. Granted the further assumption that antibiotics bind to components involved in those functions which they inhibit, this region of rRNA may well lie in the peptidyltransferase centre of the ribosome, since some MLS antibiotics appear to inhibit this function (for a review see Gale et al., 1981).

Our thanks are due to the MRC for a project grant (to E.C.) and to the SERC for a Research Fellowship (R.H.S).

\section{REFERENCES}

Bock, R. M. (1967). Alkaline hydrolysis of RNA. Methods in Enzymology 12A, 224-228.

Cundliffe, E. (1978). Mechanism of resistance to thiostrepton in the producing-organism, Streptomyces azureus. Nature, London 272, 792-795.

Cundliffe, E. \& Thompson, J. (1979). Ribose methylation and resistance to thiostrepton. Nature, London 278, 859-861.

Cundliffe, E., Dixon, P., Stark, M., Stöffler, G., Ehrlich, R., STÖFfler-MeIlicke, M. \& CANNON, M. (1979). Ribosomes in thiostrepton-resistant mutants of Bacillus megaterium lacking a single 50S subunit protein. Journal of Molecular Biology 132, 235252 .
FaHNestock, S., ERdmanN, V. \& NomUra, M. (1974). Reconstitution of 50 S ribosomal subunits from Bacillus stearothermophilus. Methods in Enzymology 30, 554-562.

Fujisawa, Y. \& Weisblum, B. (1981). A family of rdeterminants in Streptomyces spp. that specifies inducible resistance to macrolide, lincosamide, and streptogramin type B antibiotics. Journal of Bacteriology 146, 621-631.

Gale, E. F., Cundliffe, E., Reynolds, P. E., RichMOND, M. H. \& WARING, M. J. (1981). The Molecular Basis of Antibiotic Action, 2nd edn, pp. 472-473. London: J. Wiley.

GraHAM, M. Y.\& WEISBLUM, B. (1979). 23S Ribosomal 
ribonucleic acid of macrolide producing streptomycetes contains methylated adenine. Journal of Bacteriology 137, 1464-1467.

Izzo, P. \& GANTT, R. (1977). Partial purification and characterization of an $N^{2}$-guanine methylase from chicken embryos. Biochemistry 16, 3576-3581.

LAI, C-J. \& WeisBlum, B. (1971). Altered methylation of ribosomal RNA in an erythromycin-resistant strain of Staphylococcus aureus. Proceedings of the National Academy of Sciences of the United States of America 68, 856-860.

LaI, C-J., Weisblum, B., Fahnestock, S. R. \& NoMURA, M. (1973). Alteration of 23 S ribosomal ribonucleic acid and erythromycin-induced resistance to lincomycin and spiramycin in Staphylococcus aureus. Journal of Molecular Biology 74, 67-72.

McGuire, J. M., Bunch, R. L., ANDERSon, R. C., BOAZ, H. E., FlynN, E. H., Powell, H. M. \& SMITH, J. W. (1952). 'Ilotycin', a new antibiotic. Antibiotics and Chemotherapy 2, 281-283.

SANGER, F. \& BrownleE, G. G. (1976). A two-dimensional fractionation method for radioactive nucleotides. Methods in Enzymology 12A, 361-381.

SCHMIDT, G. (1957). Chemical and enzymatic methods for the identification and structural elucidation of nucleic acids and nucleotides. Methods in Enzymo$\log y$ 3, 747-775.
Shivakumar, A. G. \& Dubnau, D. (1981). Characterization of a plasmid-specified ribosome methylase associated with macrolide resistance. Nucleic Acids Research 9, 2549-2562.

Stark, M. \& Cundliffe, E. (1979). On the biological role of ribosomal protein BM-L11 of Bacillus megaterium, homologous with Escherichia coli ribosomal protein L11. Journal of Molecular Biology 134, 767779.

Tanaka, T. \& Weisblum, B. (1975). Systematic difference in the methylation of ribosomal ribonucleic acid from Gram-positive and Gram-negative bacteria. Journal of Bacteriology 123, 771-774.

Teraoka, H. \& TANAKa, K. (1974). Properties of ribosomes from Streptomyces erythreus and Streptomyces griseus. Journal of Bacteriology 120, 316-321.

Thompson, C. J., Skinner, R. H., Ward, J. M., Thompson, J., Hopwood, D. A. \& Cundliffe, E. (1982). Biochemical characterization of resistance determinants cloned from antibiotic-producing Streptomyces. Journal of Bacteriology (in the Press).

Thompson, J. \& Cundliffe, E. (1981). Purification and properties of an RNA methylase produced by Streptomyces azureus and involved in resistance to thiostrepton. Journal of General Microbiology 124, 291-297. 